finding has in many ways been as surprising as those described among the luminizers. It may be that when the target cell is the lymphocyte, and there are indications that the half-life of these cells is much longer than had hitherto been imagined (Buckton et al., 1962 ; Norman et al., 1965 ; Court Brown et al., 1965b), then further thought has to be given to the correctness of the classical concepts of the repair of chromosome breaks in regard both to the time that breaks can remain unrestituted and to the time in the cell cycle when restitution occurs.

\section{Summary}

Chromosomes were studied in cell cultures of blood from former female dial-painters containing radium ranging from non-measurable activities to 0.56 microcurie of radium-226. Incidence of structurally abnormal chromosomes was higher than that found among a random sample of females without luminizing experience. The study also demonstrated a consistent gradient of increasing structural abnormality with increase in the body content of radium.

\section{REFERENCES}

Annual Progress Report of the Massachusetts Institute of Technology. M.I.T.-952-1. May 1964.

Aub, J. C., Evans, R. D., Hempelmann, L. H., and Martland, H. S.

Bender, M. A., and Gooch, P. C. (1961). Radiat. Res., 14, 451.

Bender, M. (1962). Ibid., 16, 14 .

Bloom, A. D., and Tjio, J. H. (1964). New Engl. F. Med., 270, 1341.
Boyd, J. T. (1962). Proceedings of Seminar on Use of Vital and Health Statistics for Genetic and Radiation Studies. United Nations, New York.

Browning, E. (1949). Brit. med. f., 1, 428.

Buckton, K. E., Jacobs, P. A., Court Brown, W. M., and Doll, R. (1962). Lancet, 2, 676.

Cour Pike, M. C. (1964). Int. F. Radiat. Biol., 8, 439.

Krt Brown, W. M., Buckton, K. E., Jacobs, P. A., Tough, I. M, Kuennsberg, E. V., and Kncx, J. D.' E. (1965a). Vol. XLII Eugenics Laboratory Memoir Series, Galton Laboratory. Cambridge University Press. In press.

Evans, R. D. (1937) Aclean, A. S. (1965b). Lancet, 1, 1239

Harrison. D. (1937). Amer. F. Roentgenol., 37, 368.

G. E. (1965). Personal communication United J., Finkel, A. J., and Miller, C. E. (1964). Congress of the Unted States, 87th Congress, 2nd Session, Part II, Radiation Stanincluding Fallout, p. 943.

Hursh, J. B. (1957). Brit. F. Radiol., Suppl. No. 7, p. 45.

International Commission on Radiological Protection (1959). Report of Committee II on Permissible Dose for Internal Radiation. Pergamon Press, London.

Looney, W. B., Hasterlik, R. J., Brues, A. M., and Skirmont, E. (1955). Amer. f. Roentgenol., 73, 1006. Lucas, H. F., Rowland, R. E., Miller, C. E., Holtzman, R. B., Hasterlik, Marinelfi, L. D., Miller, C. E., and Lucas, H. F. (1962). Radiology, 78,

Martland, H. S. (1929). F. Amer. med. Ass., 92, 466.

- Conlon, P., and Knef, J. P. (1925). Ibid., 85, 1769.

Mays, C. W., Van Dilla, M. A., Floyd, R. L., and Arnold, J. S. (1958) Radiat. Res., 8, 480.

Moorhead, P. S., Nowell, P. C., Mellman, W. J., Battips, D. M., and Hungerford, D. A. (1960). Exp. Cell Res., 20, 613.

Muth, H., Schaub, A., Aurand, K., and Hantke, H. J. (1957). Brit. F. Radiol., Suppl. No. 7, p. 54.

Norman, A., Sasaki, M. S., Ottoman, R. E., and Fingerhut, A. G. (1965). Science, 147, 745 .

Norris, W. P., Speckman, T. W., and Gustafson, P. F. (1955). Amer. f. Roentgenol., 73, 785 .

Spiers, F. W. (1953). Brit. F. Radiol., 26, 296.

Vaughan, J. (1962). Int. Rev. exp. Path., 1, 244.

Vennart, J., Maycock, G., Godfrey, B. E., and Davies, B. L. (1965) Symposium on Assessment of Radioactive Body Burdens in Man. I.A.E.A., Vienna. In press.

\title{
Effects of Intrahepatic and Extrahepatic Infection on Liver Function
}

\author{
G. NEALE,* M.B., M.R.C.P. ; D. E. CAUGHEY,* $\ddagger$ M.B., CH.B. ; D. L. MOLLIN, $†$ M.B., M.R.C.P. \\ C. C. BOOTH,* M.D., F.R.C.P.
}

Brit. med. F., 1966, 1, 382-387

Abnormalities in standard hepatic function tests may sometimes be valuable in directing attention to the liver and biliary tract in patients with unexplained pyrexia. Biochemical findings may be misleading in such patients, however, for jaundice can complicate a variety of infections, such as pneumonia (Garvin, 1836; Zimmerman and Thomas, 1950), typhoid fever (Stuart and Pullen, 1946), or scarlet fever (Fishbein, 1962); and in infants with severe infections of the urinary tract marked intrahepatic biliary retention has also been described (Bernstein and Brown, 1962; Hamilton and Sass-Kortsak, 1963). Furthermore, impaired bromsulphalein (B.S.P.) excretion by the liver has frequently been recorded in patients with extrahepatic infections (Machella, 1947 ; Bradley and Conan, 1947 ; Hicks et al., 1948).

This paper describes the clinical and biochemical findings in six patients who presented with pyrexia of unknown origin and who later were found to be suffering from extrahepatic bacterial infections such as subacute bacterial endocarditis or perirenal abscess. None of these patients was jaundiced, yet there were profound biochemical disturbances of the liverfunction tests, involving impairment of B.S.P. excretion, elevation of serum alkaline phosphatase and 5-nucleotidase, and abnormalities of other enzymes. The results in these patients

* Department of Medicine, Postgraduate Medical School of London. t Department of Haematology, Postgraduate Medical School of London. $¥$ Now at Middlemore Hospital, Otahuhu, Auckland, New Zealand. are compared with those in four other patients in whom there was infection within the liver itself; three of them had liver abscesses and the fourth was suffering from portal pyelophlebitis. In these four patients similar abnormalities were demonstrated in the liver-function tests, but, in addition, the serum vitamin- $B_{12}$ concentrations were markedly elevated, in contrast to the normal levels found in the patients with extrahepatic infection.

\section{Materials and Methods}

Biochemical methods were those described by Wootton (1964).

Serum vitamin- $B_{12}$ concentrations were assayed with the $Z$ strain of Euglena gracilis (Hutner et al., 1956). The normal range with this method is from 140 to $960 \mu \mu \mathrm{g} . / \mathrm{ml}$.

Liver biopsies were performed with a Menghini needle.

\section{Patients with Extrahepatic Infection}

In the six patients with extrahepatic infection abnormalities in the liver-function tests, recorded during the initial phase of investigation and before a diagnosis had been made, erroneously suggested that the source of the infection might lie in the liver or biliary tract. The clinical features, biochemical findings, 
and response to treatment in these patients are described here, together with illustrative case reports.

\section{Clinical Features}

The clinical features of these patients are summarized in Table I. All presented with symptoms of vague ill-health and four had had recognizable episodes of fever. The duration of symptoms had varied from two or three weeks to six months. Initial clinical examination did not reveal the diagnosis. Splenomegaly was present in three patients, but the liver was neither palpable nor tender.

The temperature and erythrocyte sedimentation rate (E.S.R.) were raised in all patients, but only two (Cases 4 and 6 ) had a neutrophil leucocytosis. One patient (Case 4) had a marked normochromic anaemia (Hb 7.1 g./100 ml.), but the other five patients had haemoglobin levels close to the lower limit of normal (11.1 to $12.2 \mathrm{~g} . / 100 \mathrm{ml}$.). Blood cultures were found to be positive in four of the patients (Cases 1,2,3, and 5), though persistently negative in the other two.

Further clinical and radiological studies established the diagnosis. Two patients (Cases 1 and 2) with positive blood cultures developed cardiac murmurs while under observation, leading to a diagnosis of subacute bacterial endocarditis (S.B.E.). One patient (Case 3) had a Streptococcus viridans septicaemia due to an abscess within the substance of the right kidney. Another (Case 4) had developed a large perirenal abscess around the left kidney which had previously been damaged by extensive tuberculous infection. The fifth patient had suffered from episodes of fever for as long as five months. Extensive investigations elsewhere had failed to establish the diagnosis, but after admission a single blood culture produced a profuse growth of Escherichia coli. Subsequent investigation of the gastro-intestinal tract for a possible source of infection revealed an annular stricture of the transverse colon which was found at laparotomy to be an adenocarcinoma, without evidence of either local spread or metastasis to the liver. The final patient (Case 6) had a persistent pyrexia following a gynaecological operation and was suffering from postoperative pelvic sepsis.

\section{Hepatic Function Studies and Liver Biopsy in Extrahepatic Infection}

The hepatic function studies in the six patients are summarized in Table II.

None of the patients was jaundiced and the serum bilirubin was normal (range 0.2 to $0.5 \mathrm{mg} . / 100 \mathrm{ml}$.). The alkaline phosphatase, however, was increased in all except one patient (Case 1), levels as high as 52 and 65 King-Armstrong units (K.A.U.) being recorded in Cases 2 and 6 . The origin of the alkaline phosphatase was the liver, since there was also a marked increase in the 5-nucleotidase in the four patients in whom this was measured (Table II). There was increased retention of B.S.P. (range 14 to $30 \%$ at 45 minutes) in all the five patients in whom studies were carried out. Further observations revealed slight increases in the serum glutamic-oxaloacetic transaminase (S.G.O.T.) and serum glutamic-pyruvic transaminase (S.G.P.T.) or isocitric dehydrogenase (I.C.D.) in five patients in whom measurements of one or other of these enzymes were made.

Plasma proteins were abnormal in five of the six patients; the albumin concentrations were usually subnormal and the globulins were increased. Electrophoretic studies of the plasma proteins in these five patients demonstrated a generalized increase in the globulins particularly affecting the $\gamma$-fraction, presumably as a response to infection.

Serum $B_{12}$ concentrations were assayed in five of the six patients and were normal, ranging from 280 to $815 \mu \mu \mathrm{g} . / \mathrm{ml}$.

Liver biopsy revealed a non-specific reactive hepatitis in all six cases. There was an increase in the concentration of

TABlE I.-Clinical Features of Six Patients with Extrahepatic Infection

\begin{tabular}{|c|c|c|c|c|c|c|c|c|c|c|c|}
\hline \multirow{3}{*}{ Case } & \multirow{3}{*}{ Sex } & \multirow{3}{*}{ Age } & \multirow{3}{*}{ Presentation } & \multirow{2}{*}{\multicolumn{2}{|c|}{$\begin{array}{c}\text { Temperature } \\
\text { Range }\end{array}$}} & \multicolumn{3}{|c|}{ Haematology } & \multirow{3}{*}{$\begin{array}{l}\text { Blood } \\
\text { Culture }\end{array}$} & \multirow{3}{*}{$\begin{array}{l}\text { Diagnostic } \\
\text { Investigation }\end{array}$} & \multirow{3}{*}{ Diagnosis } \\
\hline & & & & & & & & & & & \\
\hline & & & & ${ }^{\circ} \mathrm{F}$. & ${ }^{\circ} \mathrm{C}$. & $100 \mathrm{ml}$. & 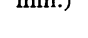 & $\left(\lim ^{\prime} .\right)^{\prime}$ & & & \\
\hline 1 & $\mathbf{M}$ & 60 & $\begin{array}{l}\text { General malaise (6 months). } \\
\text { Apathy. Splenomegaly }\end{array}$ & $98 \cdot 0-102 \cdot 0$ & $36 \cdot 7-38 \cdot 9$ & $12 \cdot 0$ & 7,000 & 50 & $\begin{array}{l}\text { Non-haemolytic } \\
\text { streptococcus }\end{array}$ & $\begin{array}{l}\text { Patient developed signs of } \\
\text { aortic incompetence }\end{array}$ & $\begin{array}{l}\text { S.B.E. on bi- } \\
\text { cuspid aortic }\end{array}$ \\
\hline 2 & $\mathbf{F}$ & 52 & $\begin{array}{l}\text { Malaise ( } 3 \text { weeks). Shivering } \\
\text { attacks. Muscle pains. } \\
\text { Splenomegaly }\end{array}$ & $98 \cdot 6-102 \cdot 4$ & $37 \cdot 0-39 \cdot 1$ & $11 \cdot 1$ & 4,000 & 72 & H. parainfluenzae & $\begin{array}{l}\text { Soft systolic murmur } \\
\text { heard at apex of heart } \\
\text { which increased in }\end{array}$ & $\begin{array}{l}\text { S.B.E. on mitral } \\
\text { valve }\end{array}$ \\
\hline 3 & $\mathbf{F}$ & 40 & $\begin{array}{l}\text { Discomfort in R. upper } \\
\text { abdomen ( } 3 \text { years). } \\
\text { rexia ( } 2 \text { weeks) }\end{array}$ & $98 \cdot 0-101 \cdot 0$ & $36 \cdot 7-38 \cdot 3$ & $11 \cdot 9$ & 4,000 & 35 & Str. viridans & $\begin{array}{l}\text { I.V.P. showed distortion } \\
\text { of caliceal pattern on } \\
\text { right }\end{array}$ & Renal abscess \\
\hline 4 & $\mathbf{F}$ & 76 & $\begin{array}{l}\text { Anaemia not responding to } \\
\text { treatment ( } 3 \text { months) }\end{array}$ & $98 \cdot 4-102 \cdot 6$ & $36 \cdot 9-39 \cdot 2$ & $7 \cdot 1$ & 15,000 & 52 & $\begin{array}{l}\text { Repeatedly } \\
\text { negative }\end{array}$ & $\begin{array}{l}\text { I. V.P. non-functioning L. } \\
\text { kidney. M.S.U.; pus } \\
\text { cells and } E \text {. coli. Pus } \\
\text { from loin: } \beta \text { haemoly- } \\
\text { tic streptococci }\end{array}$ & $\begin{array}{c}\text { Perirenal } \\
\text { abscess }\end{array}$ \\
\hline 5 & $\mathbf{F}$ & 69 & $\begin{array}{l}\text { Malaise. Weekly episodes of } \\
\text { fever for } 5 \text { months. Occa- } \\
\text { sional diarrhoea }\end{array}$ & $99 \cdot 2-101 \cdot 4$ & $37 \cdot 3-38 \cdot 6$ & $12 \cdot 2$ & 5,000 & 58 & E. coli & $\begin{array}{l}\text { Barium enema; annular } \\
\text { constricting lesion } \\
\text { transverse colon }\end{array}$ & $\begin{array}{l}\text { Adenocarcinoma } \\
\text { with surround- } \\
\text { ing inflamma- }\end{array}$ \\
\hline 6 & F & 43 & Post-operative pyrexia & $99 \cdot 0-102 \cdot 2$ & $37 \cdot 2-38 \cdot 9$ & $11 \cdot 7$ & 13,000 & 108 & $\begin{array}{l}\text { Negative } \\
(9 \text { times })\end{array}$ & $\begin{array}{c}\text { Hypogastric and pelvic } \\
\text { tenderness }\end{array}$ & $\begin{array}{l}\text { Probable pelvic } \\
\text { abscess }\end{array}$ \\
\hline
\end{tabular}

Table II.-Liver-function Tests in Six Patients with Extrahepatic Infection

\begin{tabular}{|c|c|c|c|c|c|c|c|c|c|c|c|}
\hline \multirow{2}{*}{ Case No. } & \multirow{2}{*}{$\underset{(\mathrm{mg} . / 100 \mathrm{ml} .)}{\text { Bilirubin }}$} & \multirow{2}{*}{$\begin{array}{c}\text { Alkaline } \\
\text { Phosphatase } \\
\text { (K.A.U./ } \\
\text { 100 ml.) } \\
(3-13)\end{array}$} & \multirow{2}{*}{$\begin{array}{l}\text { 5-Nucleo- } \\
\text { tidase } \\
\text { (I.U./ml.) } \\
(3-17)\end{array}$} & \multirow{2}{*}{$\begin{array}{l}\% \text { B.S.P. } \\
\text { Retention } \\
\text { at } 45 \mathrm{mins} . \\
(<5)\end{array}$} & \multirow{2}{*}{$\begin{array}{c}\text { I.C.D. } \\
\text { (I.U./mi.) } \\
(3 \cdot 0-8 \cdot 5)\end{array}$} & \multirow{2}{*}{$\begin{array}{l}\text { S.G.O.T. } \\
\underset{(5-20)}{(\text { U./ml.) }}\end{array}$} & \multirow{2}{*}{$\begin{array}{c}\text { S.G.P.T. } \\
\text { (I.U./ml.) }\end{array}$} & $\begin{array}{l}\text { Albumin } \\
(3 \cdot 0-5 \cdot 5)\end{array}$ & Globulin & \multirow{2}{*}{$\begin{array}{c}\text { Serum } B_{12} \\
(\mu \mu \mathrm{g} . / \mathrm{ml} .) \\
(140-960)\end{array}$} & \multirow{2}{*}{$\begin{array}{l}\text { Liver } \\
\text { Biopsy }\end{array}$} \\
\hline & & & & & & & & \multicolumn{2}{|c|}{$(\mathrm{g} . / 100 \mathrm{ml})}$. & & \\
\hline 1 & 0.5 & 6 & - & 30 & - & 36 & 16 & $2 \cdot 9$ & $4 \cdot 6$ & & $\begin{array}{c}\text { Non-specific } \\
\text { reactive } \\
\text { hepatitis }\end{array}$ \\
\hline $\begin{array}{l}2 \\
3 \\
4 \\
5 \\
6\end{array}$ & $\begin{array}{l}0.4 \\
0.3 \\
0.2 \\
0.2 \\
0.5\end{array}$ & $\begin{array}{l}52 \\
22 \\
45 \\
19 \\
65\end{array}$ & $\begin{array}{l}21 \\
24 \\
33 \\
75\end{array}$ & $\begin{array}{l}\frac{19}{19} \\
14 \\
27\end{array}$ & $\begin{array}{l}\bar{Z} \\
\overline{9} \\
25\end{array}$ & $\begin{array}{l}30 \\
26 \\
= \\
-\end{array}$ & $\begin{array}{l}12 \\
45 \\
= \\
-\end{array}$ & $\begin{array}{l}3 \cdot 1 \\
2 \cdot 8 \\
2 \cdot 9 \\
3 \cdot 2 \\
4 \cdot 2\end{array}$ & $\begin{array}{l}4 \cdot 0 \\
4.5 \\
4 \cdot 2 \\
2 \cdot 8 \\
3 \cdot 5\end{array}$ & $\begin{array}{l}280 \\
350 \\
815 \\
400\end{array}$ & $\begin{array}{ll}\text { " } & \text { " } \\
" & \text { ", } \\
\text { " } & \text { " }\end{array}$ \\
\hline
\end{tabular}


Kupffer cells and some infiltration of the portal tracts with inflammatory cells (Fig. 1). A portion of the liver biopsy specimen was cultured in three patients (Cases 2, 5, and 6, Table I), but the cultures were sterile.

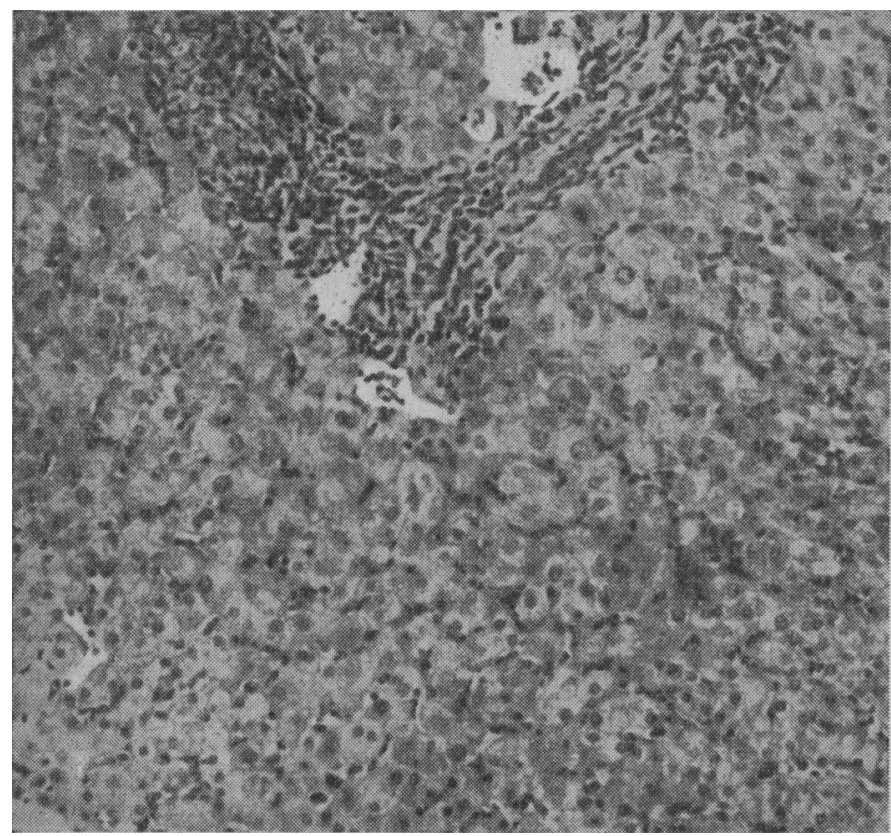

FIG. 1.-Photomicrograph of liver biopsy specimen showing non-specific reactive hepatitis. $(\times 180$.)

\section{Responses to Treatment}

The responses to treatment with antibiotics are summarized in Table III, together with studies of the serum alkaline phosphatase and B.S.P. retention before and after treatment. Serial results of the hepatic function tests are also shown in Figs. 2 and 3.

Both patients with subacute bacterial endocarditis (Cases 1 and 2) were cured of their infection, and the serum enzyme

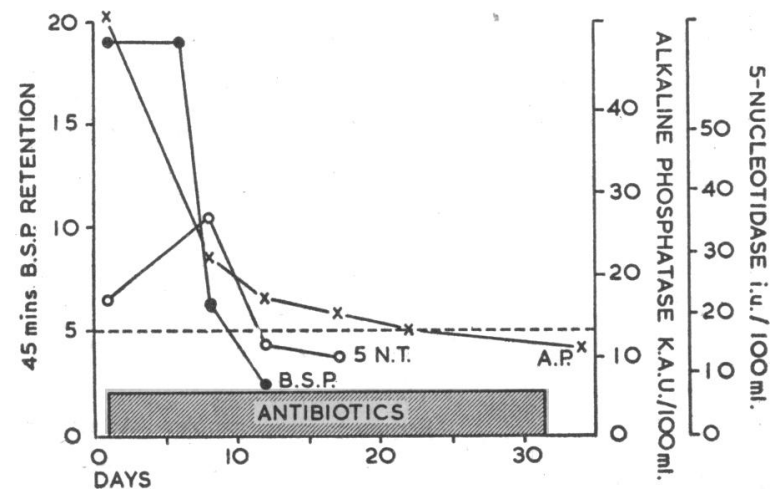

FIG. 2.-Case 2. Response to treatment. levels and B.S.P. retention returned to normal (Table III and Fig. 2). There was a similar response to antibiotics in three other patients (Cases 3, 4, and 5, Table II, Fig. 3). Studies in Case 6 were incomplete, since the patient left hospital before full recovery.

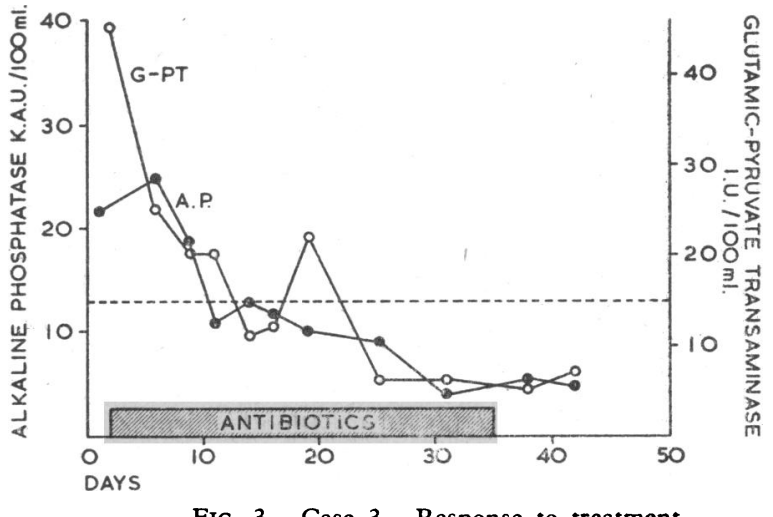

FIG. 3.-Case 3. Response to treatment.

\section{Case Reports}

\section{Case 2. Subacute Bacterial Endocarditis with Non-specific Reactive Hepatitis}

This patient had been unwell for three weeks. Her illness started with an attack of shivering, followed by generalized aches and pains. During the three days before admission to hospital she had suffered from increasing headache.

On examination in hospital she was pyrexial $\left(100.8^{\circ}\right.$ F.; $38.2^{\circ}$ C.) and looked pale and ill. There was no obvious abnormality in the cardiovascular system at this stage apart from a soft mid-systolic murmur heard at the cardiac apex. The tip of the spleen was just palpable.

Investigations.-Hb 11.1 g./100 ml.; W.B.C. 4,000/c.mm. (81\% polymorphonuclear neutrophils); E.S.R. $72 \mathrm{~mm} . / \mathrm{hr}$. (Westergren); serum albumin 3.1 g., globulin $4.0 \mathrm{~g} . / 100 \mathrm{ml}$; bilirubin $0.4 \mathrm{mg}$./ $100 \mathrm{ml}$; alkaline phosphatase 52 K.A.U./100 ml. ; 5-nucleotidase 21 I.U./ml.; thymol turbidity 5 units; zinc sulphate 4 units; S.G.O.T. 30 I.U./ml., S.G.P.T. 12 I.U./ml.; B.S.P. retention $19 \%$ at 45 minutes; C.S.F. clear fluid under normal pressure, protein $90 \mathrm{mg} . / 100 \mathrm{ml}$., sugar $58 \mathrm{mg} . / 100 \mathrm{ml}$, no cells seen, sterile on culture. Serum $\mathrm{B}_{12}$ concentration $280 \mu \mu \mathrm{g} . / \mathrm{ml}$.

Because of the elevated alkaline phosphatase and 5-nucleotidase levels, together with the abnormalities in the serum transaminases and B.S.P. retention, it was suspected that some infiltrative lesion of the liver, possibly a reticulosis, might be causing the fever. A liver biopsy was therefore performed, and this showed non-specific reactive hepatitis.

Nine days after the patient's admission to hospital the eleventh blood culture produced a small Gram-negative organism, which was subsequently identified as Haemophilus parainfluenzae. By this time the apical systolic murmur had increased in intensity and a diagnosis of subacute bacterial endocarditis involving the mitral valve was made. Apart from a transient left-upper-limb monoparesis due to a cerebral embolus, the patient made a good recovery

\begin{tabular}{|c|c|c|c|c|c|c|c|}
\hline \multirow{2}{*}{$\begin{array}{l}\text { Case } \\
\text { No. }\end{array}$} & \multirow{2}{*}{ Diagnosis } & \multirow{2}{*}{ Treatment } & \multirow{2}{*}{ Result } & \multicolumn{2}{|c|}{$\begin{array}{l}\text { Alkaline Phosphatase } \\
\text { (K.A.U./100 ml.) }\end{array}$} & \multicolumn{2}{|c|}{$\begin{array}{l}\% \text { B.S.P. Retention } \\
\text { at } 45 \text { mins. }\end{array}$} \\
\hline & & & & $\begin{array}{l}\text { Before } \\
\text { Treatment }\end{array}$ & $\begin{array}{l}\text { After } \\
\text { Treatment }\end{array}$ & $\begin{array}{l}\text { Before } \\
\text { Treatment }\end{array}$ & $\begin{array}{c}\text { After } \\
\text { Treatment }\end{array}$ \\
\hline 1 & Subacute bacterial endocarditis & $\begin{array}{l}\text { Novobiocin, erythromycin, cephalo- } \\
\text { sporin, streptomycin, vancomycin }\end{array}$ & Recovered & 6 & 6 & 30 & 6 \\
\hline $\begin{array}{l}2 \\
3 \\
4\end{array}$ & $\begin{array}{l}\text { Re”al abscess } \\
\text { Perirenal abscess }\end{array}$ & $\begin{array}{l}\text { Penicillin and streptomycin } \\
\text { Penicillin } \\
\text { Sulphonamides, penicillin, drainage }\end{array}$ & $\begin{array}{l}\text { Recovered, final I.V.P. normal } \\
\text { Sinus failed to heal. Died at }\end{array}$ & $\begin{array}{l}52 \\
22 \\
45\end{array}$ & $\begin{array}{r}11 \\
7 \\
15\end{array}$ & $\frac{19}{19}$ & $\frac{5}{6}$ \\
\hline 5 & Adenocarcinoma of colon with & Ampicillin, streptomycin, hemi- & Recovered & 19 & 11 & 14 & 5 \\
\hline 6 & Post-operative pelvic infection & Penicillin, streptomycin & $\begin{array}{l}\text { Patient returned to Egypt } \\
\text { before full recovery }\end{array}$ & 65 & 33 & 27 & - \\
\hline
\end{tabular}


after treatment with penicillin and streptomycin. The hepatic function tests simultaneously returned to normal (Fig. 2).

\section{Case 3. Renal Abscess with Non-specific Reactive Hepatitis}

Six weeks before admission this patient had an attack of pain in the right side of the abdomen radiating to the back. The pain persisted for a few days, and then subsided. Four weeks later she developed general malaise and headache, and within a few hours had a rigor. During the next 10 days she had persistent fever, anorexia, and occasional attacks of vomiting. She was then admitted to hospital.

On examination she looked ill and had a temperature of $101^{\circ} \mathrm{F}$. $\left(38.3^{\circ} \mathrm{C}.\right)$. There was slight tenderness in the right side of the abdomen but there was no other clinical abnormality. In view of the previous attack of abdominal pain the initial diagnosis was cholecystitis.

Investigations.-Hb 11.9 g./100 ml.; W.B.C. 4,000/c.mm. (49\% polymorphonuclear neutrophils); E.S.R. $35 \mathrm{~mm} . / \mathrm{hr}$. (Westergren); blood urea $32 \mathrm{mg} . / 100 \mathrm{ml}$.; serum albumin $2.8 \mathrm{~g}$., globulin $4.5 \mathrm{~g} . /$ $100 \mathrm{ml}$; bilirubin $0.3 \mathrm{mg} . / 100 \mathrm{ml}$.; alkaline phosphatase 22 K.A.U./100 ml.; thymol turbidity 2 units; zinc sulphate 5 units; S.G.O.T. 26 I.U./ml., S.G.P.T. 45 I.U./ml. Urine contained no casts, only occasional red and white cells, and no albumin; it was sterile on culture. Blood cultures were then found to be positive, Str. viridans being grown on two separate occasions.

In view of the abnormalities in the liver-function tests (elevated alkaline phosphatase and abnormal transaminases) the initial diagnosis of biliary tract disease seemed likely, but cholecystography was normal. Liver biopsy was therefore performed, and this showed a non-specific reactive hepatitis. One week later the right kidney was found to be palpable and tender. An intravenous pyelogram revealed a large filling defect in the right renal cortex. After antibiotic treatment there was spostaneous discharge of pus and blood from the kidney into the renal pelvis, causing transient pyuria and haematuria. A further pyelogram after treatment was normal, indicating that the lesion previously demonstrated was probably an abscess within the kidney substance. The abnormalities in the liverfunction tests returned to normal during treatment with antibiotics (Fig. 3).

\section{Patients with Intrahepatic Infection}

The four patients with intrahepatic infection also presented with fever of uncertain origin, and routine liver-function tests showed similar abnormalities. In contrast to the previous group, however, the serum $B_{12}$ concentrations were markedly elevated. In the first two patients the elevated serum $B_{12}$ concentrations were recorded after the diagnosis had been made; in the other two the demonstration of a high serum $B_{12}$ was of value in indicating the correct diagnosis.

\section{Clinical Features}

The clinical presentation and physical findings in the four patients with intrahepatic infection are summarized in Table IV. As in the previous group, the patients presented with symptoms of vague ill-health, fever, and rigors for periods varying between four weeks and nine years. In hospital all the patients had persistent pyrexia, ranging from 99.2 to $104.4^{\circ} \mathrm{F}$. ( 37.3 to $40.2^{\circ}$ C.), for which no cause could be found.

Physical examination was remarkably unhelpful. In the first patient, a South African holidaying in England, the liver was palpable $3 \mathrm{~cm}$. below the right costal margin but there was no tenderness even on heavy percussion. The second patient was a Nigerian medical student; the liver was not palpable, and there was only slight tenderness on very heavy percussion over the right lower thorax. The third patient had undergone partial gastrectomy one year earlier ; he was a pale, ill-looking man and had had periodic rigors, but the only abnormal physical sign was a palpable non-tender left lobe of the liver. The last patient was admitted to hospital with four weeks' history of fever. Two months previously she had had an episode of abdominal pain suggestive of appendicitis. Palpation of the right iliac fossa revealed an ill-defined non-tender mass which was thought to be a resolving appendix abscess. The liver was not palpable, but the spleen was just felt in deep inspiration.

\section{Haematological and Biochemical Findings}

Further investigation revealed haematological and biochemical abnormalities in all four patients (Tables IV and V). Three (Cases 7, 9, and 10) were anaemic; in all four there was a polymorphonuclear leucocytosis and the E.S.R. was invariably raised. Blood cultures, however, were repeatedly sterile.

Hepatic function studies demonstrated a slightly elevated serum bilirubin $(1.5 \mathrm{mg} . / 100 \mathrm{ml}$.) in only one patient (Case 8). The alkaline phosphatase was raised to between 18 and 47 K.A.U./100 ml. in Cases 8, 9, and 10, but was normal in Case 7, in whom a large intrahepatic abscess was ultimately discovered. There was increased B.S.P. retention in the two patients in whom studies were carried out $(25$ and $30 \%$ retention at 45 minutes). Transaminase levels were only slightly increased (Table V). Plasma proteins were abnormal in the three patients in whom they were measured, the albumin concentration being

TABLE IV.-Clinical Features of Four Patients with Intrahepatic Infection

\begin{tabular}{|c|c|c|c|c|c|c|c|c|c|c|}
\hline \multirow{3}{*}{$\begin{array}{l}\text { Case } \\
\text { No. }\end{array}$} & \multirow{3}{*}{ Sex } & \multirow{3}{*}{ Age } & \multirow{3}{*}{ Presentation } & \multirow{2}{*}{\multicolumn{2}{|c|}{$\begin{array}{c}\text { Range } \\
\text { of Temperature }\end{array}$}} & \multicolumn{3}{|c|}{ Haematology } & \multirow{3}{*}{$\begin{array}{l}\text { Chest } \\
x \text {-ray }\end{array}$} & \multirow{3}{*}{$\begin{array}{l}\text { Blood } \\
\text { Culture }\end{array}$} \\
\hline & & & & & & \multirow{2}{*}{$\stackrel{\mathrm{Hb}}{(\mathrm{g} . / 100 \mathrm{ml} .)}$} & \multirow{2}{*}{$\begin{array}{l}\text { W.B.C. } \\
\text { (per c.mm.) }\end{array}$} & \multirow{2}{*}{$\begin{array}{c}\text { E.S.R. } \\
\text { (Westergren) } \\
\text { (mm./hr.) }\end{array}$} & & \\
\hline & & & & ${ }^{\circ} \mathrm{F}$. & ${ }^{\circ} \mathrm{C}$. & & & & & \\
\hline 7 & $\mathbf{M}$ & 53 & $\begin{array}{l}\text { South African. P.U.O. for } 4 \text { weeks. } \\
\text { Rigors. Palpable non-tender liver }\end{array}$ & $101 \cdot 4-104 \cdot 4$ & $38 \cdot 5-40 \cdot 2$ & 8.9 & 10,000 & & \multirow{2}{*}{$\begin{array}{l}\text { R. diaphragm } \\
\text { slightly elevated } \\
\text { Normal }\end{array}$} & $\begin{array}{l}\text { Repeatedly } \\
\text { sterile }\end{array}$ \\
\hline 8 & $\mathbf{M}$ & 25 & $\begin{array}{l}\text { Intermittent pyrexia for } 9 \text { years. Impal- } \\
\text { pable liver but } R \text {. thorax tender to }\end{array}$ & $100 \cdot 4-102 \cdot 6$ & $38 \cdot 0-39 \cdot 2$ & $15 \cdot 1$ & 14,600 & 110 & & " " \\
\hline 9 & $\mathbf{M}$ & 47 & P.U.O. for 6 weeks ( 1 year after gas- & $100 \cdot 2-103 \cdot 4$ & $37 \cdot 9-39 \cdot 7$ & $10 \cdot 0$ & 25,000 & 127 & " & " \\
\hline 10 & $\mathbf{F}$ & 41 & $\begin{array}{l}\text { P.U.O. for } 4 \text { weeks. Rigors. Spleen } \\
\text { just palpable. Suggestion of mass in } \\
\text { right iliac fossa }\end{array}$ & $99 \cdot 2-102 \cdot 0$ & $37 \cdot 3-38 \cdot 9$ & $8 \cdot 0$ & 12,000 & 60 & " & " \\
\hline
\end{tabular}

TABLE V.-Liver-function Tests in Patients with Intrahepatic Infection

\begin{tabular}{|c|c|c|c|c|c|c|c|c|}
\hline \multirow{2}{*}{ Case No. } & \multirow{2}{*}{$\underset{\text { (mg./100 ml.) }}{\text { Bilirubin }}$} & \multirow{2}{*}{$\begin{array}{c}\text { Alkaline } \\
\text { Phosphatase } \\
\text { (K.A.U./100 ml.) }\end{array}$} & \multirow{2}{*}{$\begin{array}{l}\text { \% B.S.P. } \\
\text { Retention } \\
\text { at } 45 \text { mins. }\end{array}$} & S.G.O.T. & S.G.P.T. & Albumin & Globulin & \multirow{2}{*}{$\begin{array}{l}\text { Maximum } \\
\text { Serum } B_{12} \\
(\mu \mu \mathrm{g} . / \mathrm{ml} .)\end{array}$} \\
\hline & & & & \multicolumn{2}{|c|}{ (I.U./ml.) } & \multicolumn{2}{|c|}{ (g. $/ 100 \mathrm{ml})}$. & \\
\hline $\begin{array}{r}7 \\
8 \\
9 \\
10\end{array}$ & $\begin{array}{l}0.4 \\
1.5 \\
0.6 \\
0.7\end{array}$ & $\begin{array}{l}12 \\
18 \\
47 \\
23\end{array}$ & $\begin{array}{l}\bar{Z} \\
30 \\
25\end{array}$ & $\begin{array}{l}22 \\
16 \\
37 \\
23\end{array}$ & $\begin{array}{l}24 \\
25 \\
22 \\
13\end{array}$ & $\begin{array}{l}\frac{2 \cdot 5}{-} \\
2 \cdot 4 \\
2 \cdot 2\end{array}$ & $\begin{array}{l}\frac{4 \cdot 8}{5 \cdot 3} \\
4 \cdot 4\end{array}$ & $\begin{array}{l}3,340 \\
1,375 \\
2,230 \\
1,360\end{array}$ \\
\hline
\end{tabular}


reduced and the globulins increased. The most striking abnormality in these patients, however, was the serum $B_{12}$ concentration. In all four the levels were increased, and this increase was particularly marked in Cases 7 and 9, levels of 3,340 and $2,230 \mu \mu \mathrm{g} . / \mathrm{ml}$. being recorded.

\section{Diagnosis and Response to Treatment}

The diagnosis and response to treatment in the four patients are summarized in Table VI and Fig. 4.

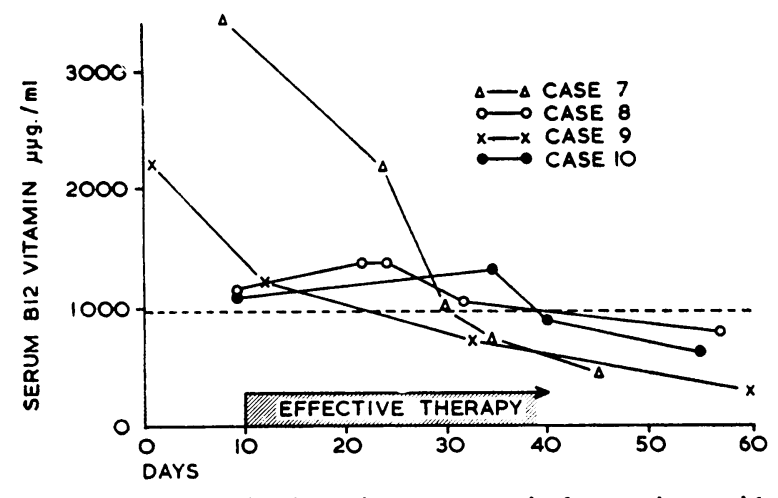

FIG. 4.-Serum $B_{12}$ levels during treatment in four patients with intrahepatic infection.

The diagnosis in all four patients was initially uncertain, and search for a possible focus of infection to explain the continued pyrexia was at first unrewarding. During investigation, however, liver biopsy was performed in all these patients, and in two (Cases 7 and 8) this gave the correct diagnosis, since pus was aspirated. In the other two patients (Cases 9 and 10) histological examination of the biopsy specimen showed marked polymorph infiltration of portal tracts and sinusoids, and the diagnosis of intrahepatic infection was suggested by the markedly elevated serum $B_{12}$ concentrations.

The initial diagnostic uncertainty and the value of the serum $\mathrm{B}_{1,2}$ concentration in the diagnosis of intrahepatic abscess is illustrated by the following case report.

\section{Case 9. Subphrenic and Hepatic Abscess Following Partial Gastrectomy}

A man aged 47 became unwell with generalized malaise and intermittent fever. On his admission to hospital no abnormality was detected on clinical examination. Blood count showed a mild polymorphonuclear leucocytosis (W.B.C. 10,000-13,000/c.mm.). The patient did not improve after treatment with antibiotics and he was transferred to Hammersmith Hospital for further investigation. One year previously he had had a partial gastrectomy for a duodenal ulcer, after which he had recovered slowly, the post-operative course being marred by two weeks' unexplained fever.

On admission to Hammersmith Hospital he was pale and illlooking with a temperature varying between 100.2 and $103.4^{\circ} \mathrm{F}$. ( 37.9 and $39.7^{\circ}$ C.). The liver and spleen were not palpable.

Investigations.- Hb 10.0 g. $/ 100 \mathrm{ml}$; W.B.C. $25,000 /$ c.mm. $(81 \%$ polymorphonuclear leucocytes); E.S.R. $127 \mathrm{~mm} . / \mathrm{hr}$; bili- rubin $0.6 \mathrm{mg} . / 100 \mathrm{ml}$. ; alkaline phosphatase 47 K.A.U./100 ml.; S.G.O.T. 37 I.U., S.G.P.T. 22 I.U./ml.; B.S.P. clearance $30 \%$ retention at 45 minutes; albumin $2.4 \mathrm{~g}$, globulin $5.3 \mathrm{~g} .1100 \mathrm{ml}$. Direct examination and culture of urine and stool revealed no pathogenic organisms. Agglutination tests were normal and repeated blood cultures were sterile. Straight $\mathbf{x}$-ray films of chest and abdomen and intravenous pyelography were normal. Serum $\mathbf{B}_{12}$ concentration, however, was now found to be markedly elevated, at $2,230 \mu \mu \mathrm{g} . / \mathrm{ml}$. This observation, together with the leucocytosis, suggested the diagnosis of intrahepatic sepsis, and a liver biopsy was therefore performed. No pus was aspirated, but the histological section showed a normal liver-cell architecture with an infiltration of lymphocytes, plasma cells, and polymorphs.

Since these findings suggested the possibility of a liver abscess, laparotomy was advised. An abscess was found in the posterior part of the left lobe of the liver, continuous with the left subphrenic space. This was drained, and treatment with antibiotics led to complete recovery. During treatment the serum $B_{1: 2}$ concentration and other hepatic function tests returned to normal.

\section{Responses to Treatment}

All four patients with intrahepatic infection recovered completely when treated with chloroquine (Case 8), antibiotics (Cases 9 and 10), or both (Case 7). The elevated serum $B_{12}$ levels fell to normal during treatment, usually within two to three weeks (Fig. 4).

\section{Discussion}

The observations described in this paper demonstrate that infection, whether intrahepatic or extrahepatic, can cause transient changes in both liver histology and function without causing jaundice. Though the abnormalities in the liverfunction tests were similar in the two groups of patients, the serum $B_{12}$ concentrations were strikingly different. The $B_{12}$ levels were markedly elevated in the patient with intrahepatic sepsis but normal in those with infection elsewhere in the body.

As already stated, jaundice has often been described in association with a variety of bacterial infections unrelated to the liver, but, with the exception of defects in B.S.P. excretion, other abnormalities of the liver-function tests have not previously been described. None of our patients with extrahepatic infection was jaundiced, but the liver-function tests were markedly abnormal. The increase in serum globulins found in all patients reflects the response of the reticuloendothelial system to infection, while the subnormal albumin levels may be due to a reduction of hepatic albumin synthesis. However, the main defect in liver function appears to involve predominantly its excretory function, for there was often a marked elevation of the serum alkaline phosphatase and 5-nucleotidase levels in addition to increased retention of B.S.P. Other enzymes were usually only slightly abnormal (Table II) and the serum $B_{12}$ level was invariably normal. These observations suggest that there was little direct hepatocellular damage in the patients studied, and this is borne out by the hepatic histology, which showed only a mild subacute reactive hepatitis without granuloma formation. There were no clearly demonstrated areas of focal necrosis, but Kupffer-cell hyper-

\section{TABLE VI.-Intrahepatic Infection. Diagnosis and Response to Treatment}

\begin{tabular}{|c|c|c|c|c|c|c|}
\hline \multirow{2}{*}{ Case No. } & \multirow{2}{*}{ Diagnostic Investigation } & \multirow{2}{*}{ Diagnosis } & \multirow{2}{*}{ Treatment } & \multirow{2}{*}{ Result } & \multicolumn{2}{|c|}{$\begin{array}{l}\text { Serum } B_{12} \text { Level } \\
(\mu \mu \mathrm{g} . / \mathrm{ml} .)\end{array}$} \\
\hline & & & & & $\begin{array}{l}\text { Before } \\
\text { Treatment }\end{array}$ & $\begin{array}{l}\text { After } \\
\text { Treatment }\end{array}$ \\
\hline 7 & Pus with liver biopsy & $\begin{array}{l}\text { Amoebic abscess with secondary } \\
\text { infection }\end{array}$ & $\begin{array}{l}\text { Chloroquine, emetine, penicillin, } \\
\text { streptomycin, chloramphenicol, } \\
\text { tetracycline, surgical drainage }\end{array}$ & Recovered & 3,340 & 450 \\
\hline $\begin{array}{l}8 \\
9\end{array}$ & $\begin{array}{l}\text { Liver biopsy showed polymorph } \\
\text { infiltration. Raised } B_{12} \text { level }\end{array}$ & $\begin{array}{l}\text { Amoebic abscess } \\
\text { Liver abscess secondary to post- } \\
\text { operative infection }\end{array}$ & $\begin{array}{l}\text { Chloroquine } \\
\text { Streptomycin, chloramphenicol, } \\
\text { surgical drainage }\end{array}$ & ’, & $\begin{array}{l}1,375 \\
2,230\end{array}$ & $\begin{array}{l}800 \\
260\end{array}$ \\
\hline 10 & ", " " " " & $\begin{array}{l}\text { Portal pyelophlebitis secondary to } \\
\text { appendicitis }\end{array}$ & Penicillin, tetracycline & & 1,360 & 760 \\
\hline
\end{tabular}


plasia was marked and in some instances there was extensive cellular infiltration around the portal tracts (Fig. 1).

It has been suggested that the Kupffer-cell hyperplasia in response to infection may lead to obstruction of the lumina of the sinusoids (Popper and Schaffner, 1957), which could explain the defect in hepatic excretory function demonstrated in our patients. The change in the liver biopsies in these patients was less pronounced than that previously described in patients dying of bacterial infection, often with jaundice, in the pre-antibiotic era (Rich, 1930 ; Klemperer, 1933). In such patients hepatic histology showed very marked infiltration of the portal tracts with inflammatory cells and patchy necrosis of parenchymal cells.

The pathogenesis of the hepatic dysfunction in patients with infection remains uncertain. It is known that the liver can remove circulating bacteria in septicaemic conditions (Wyssokowitsch, 1886; MacMahon and Mallory, 1931; Beeson et al., 1945), but bacterial invasion of the liver in our patients is unlikely, since cultures of material obtained by liver biopsy in three instances were sterile, even though blood cultures were positive at the time (Cases 2 and 5, Tables I and II). Bacterial toxins have been shown to have an effect on liver histology and function. Thus the antigen from Salmonella typhi will produce focal necrosis of liver cells (Morgan, 1943), while increased B.S.P. retention has been demonstrated in rabbits injected intravenously with bacterial endotoxins derived from $E$. coli (Hirsch et al., 1964). This explanation is not complete, however, as all our patients had pyrexia and it has been shown that fever itself may interfere with the excretion of B.S.P. (Hicks et al., 1948). The effects of fever on the liver have also been demonstrated by the observation that jaundice may occur in association with artificial hyperthermia and heat stroke (Herman and Sullivan, 1959).

In this study of patients with intrahepatic and extrahepatic sepsis we were unable to distinguish the two groups by comparison of standard liver-function tests. Serum vitamin- $B_{12}$ levels, however, gave a clear-cut differentiation. High serum $B_{12}$ levels have previously been described in a number of conditions in which there is liver-cell damage, including infective hepatitis (Rachmilewitz et al., 1956 ; Jones et al., 1957), tumours involving the liver (Grossowicz et al., 1957), congestive (ardiac failure (Rachmilewitz et al., 1959), and abscesses involving either the liver or the subphrenic space (Holdsworth et al., 1954). In the patients with septic conditions of the liver the raised serum $B_{12}$ level might be due to increased granulopoiesis; for high serum $B_{12}$ levels are found in patients with myeloproliferative disorders (Beard et al., 1954; Mollin and Ross, 1955). However, the demonstration in our patients (Case 7, Tables IV and $V$, for instance) that the serum $B_{12}$ concentration may be markedly elevated when the white-cell count is normal strongly suggests that the increase is due to breakdown of liver cells. Furthermore, very high $\mathrm{B}_{12}$ levels were not found in the patients with extrahepatic infections.

Though not diagnostic, the findings of an elevated serum $B_{12}$ concentration in a patient with pyrexia of uncertain origin (Case 9, Tables IV and V, for example) may therefore prove helpful, indicating a hepatic cause for the fever ; other hepatic function tests are less reliable and may simply be a reflection of bacterial infection elsewhere.

\section{Summary}

Ten cases of pyrexia of unknown origin are described. Abnormalities in liver-function tests without elevation of the serum bilirubin occurred in all patients irrespective of the site of infection.

Serum levels of two or more of the following enzymes: alkaline phosphatase, 5-nucleotidase, transaminases, and isocitric dehydrogenase, were raised in six patients subsequently shown to have an infective process outside the liver. Histology of liver biopsies revealed a non-specific reactive hepatitis.

In the four patients proved to have intrahepatic infection the biochemical disorders were not in any way distinguishable from those with sepsis outside the liver. Thus abnormal liverfunction tests are unhelpful in the differential diagnosis of intrahepatic and extrahepatic infection.

Serum vitamin- $\mathrm{B}_{12}$ levels were raised in all four patients with intrahepatic infection but normal in those with non-specific reactive hepatitis.

We wish to thank consultant physicians and surgeans of Hammersmith Hospital for their ready co-operation in allowing us to study patients under their care. We thank Professor I. D. P. Wootton and his staff for the biochemical investigations. One of us (G. N.) is in receipt of a grant from Smith Kline and French Ltd.

\section{REFERENCES}

Beard, M. F., Pitney, W. R., and Sanneman, E. H. (1954). Blood, 9, 789. Beeson, P. B., Brannon, E. S., and Warren, J. V. (1945). F. exp. Med., 81, 9.

Bernstein, J., and Brown, A. K. (1962). Pediatrics, 29, 873.

Bradley, S. E., and Conan, N. J. (1947). F. clin. Invest., 26, 1175.

Fishbein, W. N. (1S62). Ann. intern. Med., 57, 60.

Garvin, I. P. (1836). Sth. med. Surg., 1, 537.

Grossowicz., N., Hochman, A., Aronovitch, J., Izak, G., and Rachmilewitz, M. (1957). Lancet, 1, 1116.

Hamilton, J. R., and Sass-Kortsak, A. (1963). F. Pediat., 63, 121.

Herman, R. H., and Sullivan, B. H., jun. (1959). Amer. F. Med., 27, 154.

Hicks, M. H., Holt, H. P., Guerrant, J. L., and Leavell, B. S. (1948). f. clin. Invest., 27, 580 .

Hirsch, R. L., McKay, D. G., Travers, R. I., and Skraly, R. K. (1964). f. Lipid Res., 5, 563.

Holdsworth, C. D., Atkinson, M., Dossett, J. A., and Hall, R. (1964). Gut, 5, 601 .

Hutner, S. H., Bach, M. K., and Ross, G. I. M. (1956). F. Protozool., 3, 101 .

Jones, P. N., Mills, E. H., and Capps, R. B. (1957). f. Lab. clin. Med., 49, 910.

Klemperer, P. (1933). N.Y. St. F. Med., 33, 1309.

Machella, T. E. (1947). Amer. F. med. Sci., 213, 81.

MacMahon, H. E., and Mallory, F. B. (1931). Amer. F. Path., 7, 299.

Mollin, D. L., and Ross, G. I. M. (1955). Brit. F. Haemat., 1, 155.

Morgan, H. R. (1943). Amer. F. Path., 19, 135.

Popper, H., and Schaffner, F. (1957). Liver: Structure and Function, Chapt. 25. McGraw-Hill, New York.

Rachmilcwitz, M., Aronovitch, J., and Grossowicz, N. (1956). F. Lab. clin. Med., 48, 339.

- Stein, Y., Aronovitch, J., and Grossowicz, N. (1959). Arch. intern. Med., 104, 406.

Rich, A. R. (1930). Bull. Fohns Hopk. Hosp., 47, 338.

Stuart, B. M., and Pullen, R. L. (1946). Arch. intern. Med., 78, 629.

Wootton, I. D. P. (1964). Microanalysis in Medical Biochemistry, 4th ed. Churchill, London.

Wyssokowitsch, W. (1886). Z. Hyg. Infekt.-Kr., 1, 3.

Zimmerman, H. J., and Thomas, L. J. (1950). f. Lab. clin. Med., 35, 